\title{
p-Isothiocyanatobenzyl-desferrioxamine: a new bifunctional chelate for facile radiolabeling of monoclonal antibodies with zirconium-89 for immuno-PET imaging
}

\author{
Lars R. Perk • Maria J. W. D. Vosjan • \\ Gerard W. M. Visser • Marianne Budde • Paul Jurek • \\ Garry E. Kiefer - Guus A. M. S. van Dongen
}

Received: 16 June 2009 / Accepted: 14 August 2009/Published online: 18 September 2009

(C) The Author(s) 2009. This article is published with open access at Springerlink.com

\begin{abstract}
Purpose Immuno-PET is an emerging imaging tool for the selection of high potential antibodies (mAbs) for imaging and therapy. The positron emitter zirconium-89 $\left({ }^{89} \mathrm{Zr}\right)$ has attractive characteristics for immuno-PET with intact mAbs. Previously, we have described a multi-step procedure for stable coupling of ${ }^{89} \mathrm{Zr}$ to $\mathrm{mAbs}$ via the bifunctional chelate (BFC) tetrafluorophenol- $N$-succinyldesferal (TFP- $N$-sucDf). To enable widespread use of ${ }^{89} \mathrm{Zr}$-immuno-PET, we now introduce the novel BFC $p$-isothiocyanatobenzyl-desferriox amine B (Df-Bz-NCS) and compare its performance in ${ }^{89} \mathrm{Zr}$ immuno-PET with the reference BFC TFP- $N$-sucDf.

Methods Three mAbs were premodified with Df-Bz-NCS and labeled with ${ }^{89} \mathrm{Zr}$ at different $\mathrm{pHs}$ to assess the reaction kinetics and robustness of the radiolabeling. Stability of both ${ }^{89} \mathrm{Zr}$-Df-Bz-NCS- and ${ }^{89} \mathrm{Zr}-N$-sucDf-conjugates was evaluated in different buffers and human serum. Comparative biodistribution and PET studies in tumor-bearing mice were undertaken.
\end{abstract}

Lars Perk and Maria Vosjan contributed equally to this article.

L. R. Perk • M. J. W. D. Vosjan • M. Budde •

G. A. M. S. van Dongen $(\triangle)$

Department of Otolaryngology/Head and Neck Surgery,

VU University Medical Center,

De Boelelaan 1117, PO Box 7057, 1007 MB, Amsterdam,

The Netherlands

e-mail: gams.vandongen@vumc.nl

G. W. M. Visser - G. A. M. S. van Dongen

Nuclear Medicine \& PET Research,

VU University Medical Center,

Amsterdam, The Netherlands

P. Jurek · G. E. Kiefer

Macrocyclics Inc.,

Dallas, TX, USA
Results The selected conjugation conditions resulted in a chelate:mAb substitution ratio of about 1.5:1. Under optimal radiolabeling conditions $(\mathrm{pH}$ between 6.8-7.2), the radiochemical yield was $>85 \%$ after 60 min incubation at room temperature, resulting in radioimmunoconjugates with preserved integrity and immunoreactivity. The new radioimmunoconjugate was very stable in serum for up to 7 days at $37^{\circ} \mathrm{C}$, with $<5 \%{ }^{89} \mathrm{Zr}$ release, and was equally stable compared to the reference conjugate when stored in the appropriate buffer at $4^{\circ} \mathrm{C}$. In biodistribution and imaging experiments, the novel and the reference radioimmunoconjugates showed high and similar accumulation in tumors in nude mice.

Conclusions The novel Df-Bz-NCS BFC allows efficient and easy preparation of optimally performing ${ }^{89} \mathrm{Zr}$-labeled $\mathrm{mAbs}$, facilitating further exploration of ${ }^{89} \mathrm{Zr}$-immuno-PET as an imaging tool.

Keywords Positron emission tomography - Zirconium-89 . Bifunctional chelate - Desferrioxamine - Antibodies .

Radiolabeling

\section{Introduction}

Presently, hundreds of monoclonal antibodies (mAbs) and $\mathrm{mAb}$ fragments are under clinical development because of their excellent potential for diagnosis and systemic treatment of cancer and other pathological conditions [1]. Positron emission tomography (PET) offers an attractive imaging option to confirm and quantify selective tumor uptake of such targeting molecules [2-4].

To enable PET imaging of intact $\mathrm{mAbs}$ and $\mathrm{mAb}$-fragments (immuno-PET), an appropriate positron emitter, with a half-life 
$\left(t_{1 / 2}\right)$ that is compatible with the time needed to achieve optimal tumor-to-nontumor ratios (typically 2-4 days for intact $\mathrm{mAbs}$, and $2-4 \mathrm{~h}$ for $\mathrm{mAb}$-fragments), has to be securely coupled to the targeting molecule. Among others, the following positron emitters for immuno-PET are under investigation at the moment: gallium-68 $\left({ }^{68} \mathrm{Ga} ; \mathrm{t}_{1 / 2}: 1.13 \mathrm{~h}\right)$, fluorine-18 $\left({ }^{18} \mathrm{~F} ; \mathrm{t}_{1 / 2}: 1.83 \mathrm{~h}\right)$, copper-64 $\left({ }^{64} \mathrm{Cu} ; \mathrm{t}_{1 / 2}: 12.7 \mathrm{~h}\right)$, yttrium-86 $\left({ }^{86} \mathrm{Y} \mathrm{t}_{1 / 2}: 14.7 \mathrm{~h}\right)$, bromine-76 $\left({ }^{76} \mathrm{Br} ; \mathrm{t}_{1 / 2}: 16.2 \mathrm{~h}\right)$, zirconium-89 $\left({ }^{89} \mathrm{Zr} ; \mathrm{t}_{1 / 2}: 78.4 \mathrm{~h}\right)$, and iodine-124 $\left({ }^{124} \mathrm{I} \mathrm{t}_{1 / 2}\right.$ : $100.3 \mathrm{~h}$ ). Another important consideration in the choice of a positron emitter is whether the $\mathrm{mAb}$ or $\mathrm{mAb}$ fragment becomes internalized after binding to the target antigen. In that case, a positron emitter is needed that residualizes in the target cell after internalization, like ${ }^{68} \mathrm{Ga},{ }^{64} \mathrm{Cu},{ }^{86} \mathrm{Y}$, and ${ }^{89} \mathrm{Zr}$, to enable imaging at optimal contrast. These radionuclides have to be attached via chelating agents to $\mathrm{mAbs}$ and $\mathrm{mAb}$-fragments.

For the imaging of intact mAbs with PET, we recently described the large-scale production of ${ }^{89} \mathrm{Zr}$ and a strategy for labeling mAbs with ${ }^{89} \mathrm{Zr}$ via a multi-step synthesis using a succinylated-derivative of desferrioxamine B ( $N$-sucDf ) as bifunctional chelate [5]. The utility of this approach was clearly demonstrated through high-quality ${ }^{89} \mathrm{Zr}-\mathrm{mAb}-\mathrm{PET}$ images reported in preclinical and clinical studies [6-13]. The choice of desferrioxamine $B$ is attractive because it is used clinically in a safe way for many years. The upcoming commercialization of ${ }^{89} \mathrm{Zr}$ will make this radionuclide broadly available for research and clinical applications.

A shortcoming of the aforementioned labeling approach is that the multi-step procedure is relatively complicated and timeconsuming, and therefore challenging with respect to Good Manufacturing Practice (GMP) compliancy. We now introduce a newly developed $p$-isothiocyanatobenzyl-derivative of desferrioxamine B (Df-Bz-NCS; Macrocyclics, TX) that enables an efficient and rapid preparation of ${ }^{89} \mathrm{Zr}$-labeled mAbs.

The chemical characterization of Df-Bz-NCS, its subsequent coupling to $\mathrm{mAbs}$, and the radiolabeling of Df-BzNCS conjugated mAbs with ${ }^{89} \mathrm{Zr}$, are described. The in vitro stability of ${ }^{89} \mathrm{Zr}$-Df-Bz-NCS-mAb conjugates is compared with the corresponding ${ }^{89} \mathrm{Zr}-N$-sucDf-mAb conjugates. In addition, comparative biodistribution and animal-PET studies are presented.

\section{Materials and methods}

Materials, monoclonal antibodies, cell lines, and radioactivity

All reagents were obtained from Sigma-Aldrich (St. Louis, MO) unless otherwise stated. No special measures were taken regarding working under strict metal-free conditions. Deionized water (18 M $\Omega$ ) was used in all reactions. Df-Bz-
NCS was obtained from Macrocyclics (cat. no. B-705). MAb cetuximab (Erbitux; $2.0 \mathrm{mg} / \mathrm{ml}$ ) directed against the epidermal growth factor receptor (EGFR) was purchased from Merck (Darmstadt, Germany) [14]. Selection, production, and characterization of chimeric mAb U36 (cU36; $11.53 \mathrm{mg} / \mathrm{ml}$ ) directed against CD44v6 has been described elsewhere [15]. MAb rituximab (MabThera; $10 \mathrm{mg} / \mathrm{ml}$ ) directed against CD20 was purchased from Roche Nederland BV (Woerden, The Netherlands).

The human epidermoid cervical carcinoma cell line A431 and the CD20+ B-cell lymphoma cell line Ramos were both obtained from the American Type Culture Collection (www.atcc.com, ATCC number: CRL-1555 and CRL-1596, respectively). The head and neck squamous cell carcinoma (HNSCC) cell line $\mathrm{FaDu}$ was obtained from Karl-Heinz Heider (Boehringer Ingelheim, Vienna, Austria) [16], and the HNSCC cell line UM-SCC-11B was obtained from Dr. T.E. Carey (Ann Arbor, MI)[17].

${ }^{89} \mathrm{Zr}\left(T_{1 / 2}=78.4 \mathrm{~h}, \beta^{+}=22.6 \% ; \sim 2.7 \mathrm{GBq} / \mathrm{ml}\right.$ in $1 \mathrm{M}$ oxalic acid) was produced by BV Cyclotron VU (Amsterdam, The Netherlands) by a $(\mathrm{p}, \mathrm{n})$ reaction on natural yttrium-89 $\left({ }^{89} \mathrm{Y}\right)$ and isolated with a hydroxamate column [5].

Characterization of p-Isothiocyanatobenzyldesferrioxamine (Df-Bz-NCS)

Synthesis of the new ligand 1-(4-isothiocyanatophenyl)-3[6,17-dihydroxy-7,10,18,21-tetroxo-27-[N-acetylhydroxya mino)-6,11,17,22-tetraazaheptaeicosane)thiourea (p-isothio cyanato-benzyl-desferrioxamine; Df-Bz-NCS) was performed by Macrocyclics (Dallas, TX) as described before [18]. In short, Desferrioxamine B mesylate (Df; Desferal, Novartis, Basel) was dissolved in isopropanol/water while gently stirring. A chloroform solution of 1,4-phenylendiisothiocya nate and triethyl amine was then added and the reaction progress was monitored by reverse-phase HPLC. Upon completion, the reaction mixture was extracted with $0.1 \mathrm{M}$ $\mathrm{HCl}$. The lower organic layer was concentrated in vacuo to remove the chloroform but not the isopropanol. The remaining organic solution was purified by reverse-phase preparative HPLC using a water/acetonitrile gradient [Detector: UV/VIS at $275 \mathrm{~nm}$. Column: Phenomenex Luna C18 (2) $(250 \times 50 \mathrm{~mm}, 10 \mu \mathrm{m})$. Sample prep: Direct injection of the isopropanol solution. Mobile phase: 0-10 $\mathrm{min} 40 / 60 \mathrm{~A} /$ $\mathrm{B}$; $10-15 \mathrm{~min} \mathrm{ramp} 40 / 60$ to $90 / 10 \mathrm{~A} / \mathrm{B} ; 15-25 \mathrm{~min} 90 / 10$ $\mathrm{A} / \mathrm{B} ; \mathrm{A}=\mathrm{CH}_{3} \mathrm{CN}, \mathrm{B}=\mathrm{H}_{2} \mathrm{O}$. Flow rate $=100 \mathrm{ml} / \mathrm{min}$. Retention time of product was $\sim 10 \mathrm{~min}$. Desired fractions were placed at $-20^{\circ} \mathrm{C}$ to precipitate the product. The final product was isolated by filtration as a white solid (41\% yield).

Analytical data ${ }^{1} \mathrm{H}$ NMR (D $\left.-\mathrm{DMSO}\right): \delta 1.21\left(\mathrm{~m},-\mathrm{CH}_{2}\right.$, $6 \mathrm{H}), 1.38\left(\mathrm{~m},-\mathrm{CH}_{2}, 4 \mathrm{H}\right), 1.95\left(\mathrm{~s},-\mathrm{CH}_{3}, 3 \mathrm{H}\right), 2.27\left(\mathrm{~m},-\mathrm{CH}_{2}\right.$, 4H), 2.99 (m, $\left.\mathrm{CH}_{2}, 4 \mathrm{H}\right), 3.45$ (m, $\left.\mathrm{CH}_{2}, 8 \mathrm{H}\right), 7.35$ (d, 2,6-ArH, 
$\mathrm{J}=8.9 \mathrm{~Hz}, 2 \mathrm{H}), 7.75$ (d, 3,5=ArH, J=8.9 Hz, 2H), 7.75 (m, N-H, 2H), 7.88 (bs, N-H, 1H), 9.59 (m, N-OH, 4H). ${ }^{13} \mathrm{C}$ NMR: $\delta 19.18\left(\mathrm{CH}_{3}\right), 22.34,22.35,22.44,24.88,24.90$, 24.94, 24.96, 24.98, 26.42, 26.88, 27.66, 28.78, 28.79, 28.83, $37.28,37.92,42.57,42.60,42.63,45.67,45.97,121.92$, $123.50,124.98,131.58,138.17(\mathrm{~N}=\mathrm{C}=\mathrm{S}), 169.00(\mathrm{C}=\mathrm{O})$, $170.20(\mathrm{C}=\mathrm{O}), 170.84(\mathrm{C}=\mathrm{O}), 179.02(\mathrm{C}=\mathrm{S})$. Elemental analysis calculated (\%) for $\mathrm{C}_{33} \mathrm{H}_{52} \mathrm{~N}_{8} \mathrm{O}_{8} \mathrm{~S}_{2}$ : C 52.64, H 6.96, $\mathrm{N} 14.88$, S 8.52, found C 52.43, H 7.08, N 14.81, S 8.59. m/z: $(\mathrm{ESI}+) ; 775\left(100 \%[\mathrm{M}+\mathrm{Na}]^{+}\right),(\mathrm{ESI}-) ; 751(100 \%[\mathrm{M}-\mathrm{H}])$. Chromatographic purity: $>98 \%$ Detector: UV/VIS at $225 \mathrm{~nm}$. Column: Restek Ultra IBD $(100 \times 4.6 \mathrm{~mm}, 3 \mu \mathrm{m}, 100 \mathrm{~A})$. Sample prep: a $1.0 \mathrm{mg} / \mathrm{ml}$ solution prepared in DMSO. Mobile phase: $0-10$ min ramp $5 / 95$ to $95 / 5 \mathrm{~A} / \mathrm{B} ; 10-15 \mathrm{~min}$ $95 / 5 \mathrm{~A} / \mathrm{B} ; \mathrm{A}=0.1 \%$ TFA in $\mathrm{CH}_{3} \mathrm{CN}, \mathrm{B}=0.1 \%$ TFA in $\mathrm{H}_{2} \mathrm{O}$.

\section{Preparation of ${ }^{89} \mathrm{Zr}$-labeled Df-Bz-NCS-mAb}

cU36, cetuximab, or rituximab were premodified with DfBz-NCS (Fig. 1a). In short, while gently shaking, a threefold molar excess of Df-Bz-NCS (in $20 \mu \mathrm{l}$ DMSO) was added to the $\mathrm{mAb}\left(2-10 \mathrm{mg}\right.$ in $1 \mathrm{ml} 0.1 \mathrm{M} \mathrm{NaHCO}_{3}$ buffer, $\mathrm{pH}$ 9.0), and incubated for $30 \mathrm{~min}$ at $37^{\circ} \mathrm{C}$. Nonconjugated chelate was removed by size exclusion chromatography using a PD10 column (GE Healthcare Life Sciences) and $0.9 \%$ sodium chloride/gentisic acid $5 \mathrm{mg} / \mathrm{ml}(\mathrm{pH} 5.0)$ as eluent. Subsequently, Df-Bz-NCS-mAb was labeled with ${ }^{89} \mathrm{Zr}$ at room temperature in a volume of $2 \mathrm{ml}$ for $60 \mathrm{~min}$; to $200 \mu{ }^{89} \mathrm{Zr}(37-250 \mathrm{MBq})$ solution $90 \mu \mathrm{l} 2 \mathrm{M} \mathrm{Na}_{2} \mathrm{CO}_{3}$ were added, after $3 \mathrm{~min} 300 \mu \mathrm{l} 0.5 \mathrm{M}$ HEPES buffer $(\mathrm{pH}$ 7.0), $710 \mu \mathrm{l}$ Df-Bz-NCS-mAb (1-2 mg) and $700 \mu \mathrm{l} 0.5 \mathrm{M}$ HEPES ( $\mathrm{pH}$ 7.0) were added. Other $\mathrm{pH}$ values were obtained by adjusting the HEPES buffer to chosen $\mathrm{pH}$ values. Finally, ${ }^{89} \mathrm{Zr}$-Df-Bz-NCS-mAb was purified by size exclusion chromatography (PD10 column) using $0.25 \mathrm{M}$ sodium acetate/gentisic acid $5 \mathrm{mg} / \mathrm{ml}$ buffer ( $\mathrm{pH} 5.5$ ) or $0.9 \%$ sodium chloride/gentisic acid $5 \mathrm{mg} / \mathrm{ml}$ (pH 5.0) as the mobile phase.

\section{Preparation of ${ }^{89} \mathrm{Zr}$-labeled $N$-sucDf-mAb}

As reference to the new method for ${ }^{89} \mathrm{Zr}$ labeling, Df was also coupled to $\mathrm{mAbs}$ via the multi-step procedure as previously described by Verel et al. [5] (Fig. 1b). In short, the chelate Df was succinylated ( $N$-sucDf), temporarily filled with stable iron $[\mathrm{Fe}(\mathrm{III})]$, and coupled to the lysine residues of the mAb (cU36 or cetuximab) by means of a tetrafluorophenol- $N$-sucDf ester. After removal of $\mathrm{Fe}$ (III) by transchelation to EDTA at $35^{\circ} \mathrm{C}$, the premodified $\mathrm{mAb}$ was purified on a PD10 column. Approximately $1 \mathrm{~N}$-sucDf moiety was coupled per mAb molecule. Subsequently, $\mathrm{N}$ sucDf-mAb was labeled with ${ }^{89} \mathrm{Zr}$ in $0.25 \mathrm{M}$ HEPES buffer at pH 7.0; to $200 \mu 1{ }^{89} \mathrm{Zr}$ (37-185 MBq) solution $90 \mu \mathrm{l} 2 \mathrm{M}$ $\mathrm{Na}_{2} \mathrm{CO}_{3}$ were added, after $3 \min 300 \mu \mathrm{l} 0.5 \mathrm{M}$ HEPES buffer (pH 7.0), $710 \mu \mathrm{l} N$-SucDf-mAb (1-2 mg) and $700 \mu \mathrm{l}$ $0.5 \mathrm{M}$ HEPES (pH 7.0) were added. Finally, ${ }^{89} \mathrm{Zr}-\mathrm{N}$-sucDf$\mathrm{mAb}$ was purified on a PD10 column using $0.9 \%$ sodium chloride/gentisic acid $5 \mathrm{mg} / \mathrm{ml}$ (pH 5.0) or $0.25 \mathrm{M}$ sodium acetate/gentisic acid $5 \mathrm{mg} / \mathrm{ml}$ buffer (pH 5.5) as the mobile phase.

\section{Analyses}

After each preparation of ${ }^{89} \mathrm{Zr}$-labeled Df-Bz-NCS-mAb or $N$-sucDf-mAb, the conjugates were analyzed by instant thin-layer chromatography (ITLC) for radiolabeling efficiency and radiochemical purity, and by high-performance liquid chromatography (HPLC) and sodium dodecyl sulfate-polyacrylamide gel electrophoresis (SDS-PAGE) followed by phosphor imager analyses for integrity, and by a cell-binding assay for immunoreactivity.

ITLC analyses of ${ }^{89} \mathrm{Zr}$-labeled $\mathrm{N}$-sucDf-mAb or Df-BzNCS-mAb was performed on silica gel impregnated glass fiber sheets (Pall Corp., East Hills, NY). As the mobile phase, $0.02 \mathrm{M}$ citrate buffer ( $\mathrm{pH}$ 5.0) was used.

HPLC monitoring of the final products was performed on a Jasco HPLC system using a Superdex 200 10/300 GL size exclusion column (GE Healthcare Life Sciences). As eluent, a mixture of $0.05 \mathrm{M}$ sodium phosphate and $0.15 \mathrm{M}$ sodium chloride ( $\mathrm{pH} 6.8$ ) was used at a flow rate of $0.5 \mathrm{ml} /$ min. Electrophoresis was performed on a Phastgel System (GE Healthcare Life Sciences) using preformed 7.5\% SDSPAGE gels under non-reducing conditions.

The immunoreactivity was determined by measuring binding of ${ }^{89} \mathrm{Zr}$-cU36, ${ }^{89} \mathrm{Zr}$-cetuximab, or ${ }^{89} \mathrm{Zr}$-rituximab $(10,000 \mathrm{cpm} / \mathrm{ml})$ to a serial dilution of $0.2 \%$ glutaraldehydefixed 11B cells or $2 \%$ paraformaldehyde-fixed A431, or Ramos cells, respectively, essentially as described by Lindmo et al. [19].

\section{Determination of chelate-to-mAb ratio}

The Df-Bz-NCS to mAb molar ratio was determined following a general method as described by Meares et al. [20]. In short, conjugates were labeled according to the aforementioned procedure with a known nanomolar excess of zirconium oxalate solution spiked with ${ }^{89} \mathrm{Zr}$.

In vitro stability

For assessment of the in vitro stability of ${ }^{89} \mathrm{Zr}$-Df-Bz-NCS$\mathrm{mAb}$ in comparison with the reference conjugate ${ }^{89} \mathrm{Zr}-\mathrm{N}$ sucDf-mAb, two sets of experiments were performed. In a first set, labeled $\mathrm{mAbs}$ were stored at $4^{\circ} \mathrm{C}$ (storage and transportation conditions) and room temperature in $0.9 \%$ 

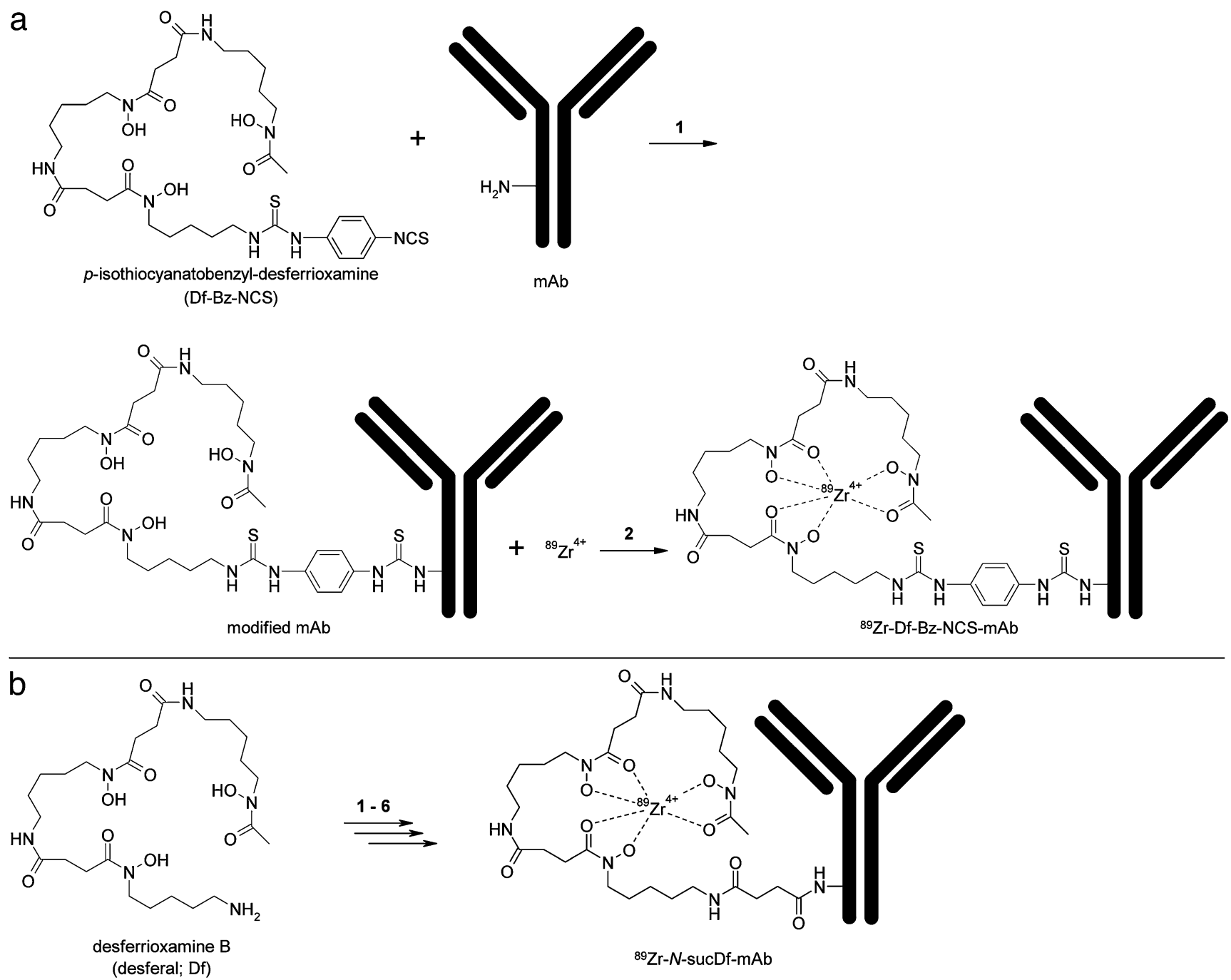

Fig. 1 Schematic representation of mAb modification with the new bifunctional chelate Df-Bz-NCS (1) and subsequent labeling with ${ }^{89} \mathrm{Zr}(\mathbf{2})(\mathbf{a})$. The multi-step reference procedure using desferrioxamine B as starting ligand (b)

$\mathrm{NaCl} /$ gentisic acid $5 \mathrm{mg} / \mathrm{ml}$ or $0.25 \mathrm{M}$ sodium acetate/ gentisic acid $5 \mathrm{mg} / \mathrm{ml}$. Final activity concentration was between $30-40 \mathrm{MBq} / \mathrm{ml}$, specific activity was between $67-$ $86 \mathrm{MBq} / \mathrm{mg} \mathrm{mAb}$. At various time points, aliquots were taken and analyzed by ITLC, SDS-PAGE, and HPLC.

In a second set, purified radiolabeled mAbs were added to freshly prepared human serum $(1: 4 \mathrm{v} / \mathrm{v}$ dilution; sodium azide added to $0.02 \%$ ) at a final concentration of the radiolabeled conjugates of $\sim 1.3 \mathrm{nmol} / \mathrm{ml}$ and $\sim 45 \mathrm{MBq} / \mathrm{ml}$. The samples were incubated at $37^{\circ} \mathrm{C}$ in a $\mathrm{CO}_{2}$-enriched atmosphere $\left(5 \% \mathrm{CO}_{2}\right)$. At various time points, aliquots were taken and analyzed by TLC, SDS-PAGE, and HPLC.

Evaluation of in vivo biodistribution

For assessment of biodistribution and the in vivo stability of the new ${ }^{89} \mathrm{Zr}$-Df-Bz-NCS-mAb conjugate in comparison with the established ${ }^{89} \mathrm{Zr}-\mathrm{N}$-sucDf-mAb conjugate, two sets of experiments were performed with nude mice bearing subcutaneously implanted human xenografts of the HNSCC line $\mathrm{FaDu}$ or the vulvar tumor line $\mathrm{A} 431$ at two lateral sides. In one experiment, the moderately internalizing cU36 mAb was tested; in the other, the extensively internalizing $\mathrm{mAb}$ cetuximab [21]. Female mice (HSD: Athymic Nude-Foxn $1^{n u}, 21-31 \mathrm{~g}$; Harlan) were 8 to 10 weeks old at the time of the experiments. All animal experiments were done according to the NIH Principles of Laboratory Animal Care and Dutch national law ("Wet op de dierproeven", Stb 1985, 336).

In a first experiment, mice bearing $\mathrm{FaDu}$ xenografts (two groups of $n=8$ ) were injected intravenously (i.v.) with either ${ }^{89} \mathrm{Zr}$-Df-Bz-NCS-cU36 $(0.38 \pm 0.01 \mathrm{MBq})$ or the reference compound ${ }^{89} \mathrm{Zr}-\mathrm{N}$-sucDf-cU36 (0.38 $0.01 \mathrm{MBq}$ ). Unlabeled $\mathrm{mAb} \mathrm{cU} 36$ was added to the injection mixture to bring the total $\mathrm{mAb}$ dose to $100 \mu \mathrm{g}$ per mouse. At 72 and $144 \mathrm{~h}$ post-injection, four mice of 
each group were anesthetized, bled, killed, and dissected. After blood, tumor, and normal tissues had been weighed, the amount of radioactivity in each sample was measured in a gamma counter. Radioactivity uptake was calculated as the percentage of the injected dose per gram of tissue $(\% \mathrm{ID} / \mathrm{g})$.

In a second experiment, mice bearing A431 xenografts (two groups of $n=16$ ) were injected i.v. with either ${ }^{89} \mathrm{Zr}$-Df-Bz-NCS-cetuximab $(0.24 \pm 0.01 \mathrm{MBq})$ or the reference compound ${ }^{89} \mathrm{Zr}-\mathrm{N}$-sucDf-cetuximab $(0.24 \pm$ $0.01 \mathrm{MBq}$ ). Unlabeled cetuximab was added to the injection mixture to bring the total $\mathrm{mAb}$ dose to $500 \mu \mathrm{g}$ per mouse. At 24, 48, 72, and $120 \mathrm{~h}$ post-injection, four mice of each group were anesthetized, bled, killed, and dissected, with further processing according to the above procedure.

\section{PET study}

PET imaging was performed on a double-crystal-layer HRRT PET scanner (Siemens/CTI), a dedicated small animal and human brain scanner, as described earlier $[7,22]$. FaDu xenograft-bearing nude mice (two groups of $n=3)$ were anesthetized by inhalation of $2 \%$ isoflurane, injected with either $4.12 \pm 0.04 \mathrm{MBq}{ }^{89} \mathrm{Zr}$-Df-Bz-NCScU36 $(\sim 200 \mu \mathrm{g} \mathrm{mAb})$ or $4.03 \pm 0.09 \mathrm{MBq}{ }^{89} \mathrm{Zr}-N$-sucDfcU36 $(\sim 200 \mu \mathrm{g} \mathrm{mAb})$ via the retroorbital plexus, and scanned at $72 \mathrm{~h}$ post-injection.

Transmission scans for attenuation and scatter correction were routinely obtained with each scan in twodimensional mode using a single point ${ }^{137} \mathrm{Cs}$ source. Three-dimensional emission scans were acquired in 64bit list mode during $60 \mathrm{~min}$ using a $400-650 \mathrm{keV}$ window. The 64-bit list mode file was first converted into a single-frame histogram using a span of nine, and subsequently reconstructed using a 3D ANW-OSEM reconstruction algorithm with two iterations and 16 subsets and a matrix size of $256 \times 256$, including corrections for normalization, decay, and dead time. For visualization of the images, Amide's A Medical Imaging Data Examiner (AMIDE) was used, freely available for download online [23]. Immediately after the PET scan the animals were killed, and blood, tumors, major organs, and tissues were collected, weighed, and counted in a gamma-counter.

\section{Statistical analyses}

Differences in tissue uptake between injected conjugates were statistically analyzed for each time point with SPSS 15.0 software using Student's $t$-test for unpaired data. Two-sided significance levels were calculated and $P<0.01$ was considered statistically significant.

\section{Results}

Preparation of ${ }^{89} \mathrm{Zr}-\mathrm{Df}-\mathrm{Bz}-\mathrm{NCS}-\mathrm{mAb}$

${ }^{89} \mathrm{Zr}$-Df-Bz-NCS-mAb was prepared according to the chemical route as shown in Fig. 1a. First, Df-Bz-NCS is coupled to the lysine groups of a mAb. Conjugation conditions selected for this step comprised the addition of a three-fold molar excess of Df-Bz-NCS to the mAb solution (13-66 nmol mAb), a reaction $\mathrm{pH}$ of 9.0, and incubation for $30 \mathrm{~min}$ at $37^{\circ} \mathrm{C}$. These conditions resulted in a reproducible chelate:mAb substitution ratio of about 1.5:1, irrespective cU36, cetuximab or rituximab was used, as assessed by trace labeling with ${ }^{89} \mathrm{Zr}$ in a standard solution of $\mathrm{Zr}$-oxalate.

In the next step, Df-Bz-NCS-mAbs were labeled with ${ }^{89} \mathrm{Zr}$ in HEPES buffer (final concentration $0.25 \mathrm{M}$ ). After 60 min incubation at room temperature at $\mathrm{pH}$ 6.8-7.2, the amount of ${ }^{89} \mathrm{Zr}$ trans-chelated from oxalate to Df-Bz-NCS$\mathrm{mAb}$ was always more than $85 \%$ (mean, $91.9 \pm 4.6 \%$ ). The time courses of ${ }^{89} \mathrm{Zr}$-complexation of mAb cU36 conjugated with Df-Bz-NCS at different pHs are shown in Fig. 2. Labeling efficiency was distinctly higher at $\mathrm{pH} 6.8$ and 7.2 than at $\mathrm{pH}$ 6.0, 6.2, and 7.4.

Labeling of mAb cU36, cetuximab, or rituximab modified with Df-Bz-NCS resulted in overall yields after purification of always $>80 \%$ (mean, $87.0 \pm 4.6 \%$ ). The radiochemical purity was always $>95 \%$ (mean, $97.5 \pm$ $0.7 \%$; determined with ITLC and confirmed by HPLC). The immunoreactive fraction of the different ${ }^{89} \mathrm{Zr}$-Df-BzNCS-mAb preparations ranged from 84.1 to $96.8 \%$ at the highest cell concentration, and was similar to those of their ${ }^{131}$ I-labeled counterparts (data not shown). HPLC and SDSPAGE analyses revealed optimal integrity of the different mAbs after modification and labeling with ${ }^{89} \mathrm{Zr}$ (data not shown).

Evaluation of the in vitro stability

${ }^{89} \mathrm{Zr}$-labeled Df-Bz-NCS-mAb and $N$-sucDf-mAb conjugates were both stored in $0.9 \% \mathrm{NaCl} /$ gentisic acid $5 \mathrm{mg} / \mathrm{ml}$ and in $0.25 \mathrm{M}$ sodium acetate/gentisic acid $5 \mathrm{mg} / \mathrm{ml}$ at $4{ }^{\circ} \mathrm{C}$ over several days to evaluate the in vitro stability. To anticipate effects of insufficient cooling, the conjugates were also analyzed after storage at room temperature $\left(21^{\circ} \mathrm{C}\right)$. Storing the ${ }^{89} \mathrm{Zr}$-Df-Bz-NCS-mAb conjugates in $0.25 \mathrm{M}$ sodium acetate/gentisic acid $5 \mathrm{mg} / \mathrm{ml}$ buffer (pH 5.5) at $4{ }^{\circ} \mathrm{C}$ gave the best results; only $0.9 \pm 0.4 \%$ of the initially bound ${ }^{89} \mathrm{Zr}$ was dissociated from the $\mathrm{mAb}$ after $48 \mathrm{~h}$, and $4.1 \pm 1.3 \%$ after $144 \mathrm{~h}$. Upon storage in the same buffer at room temperature $\left(21^{\circ} \mathrm{C}\right), 6.1 \pm 1.4 \%$ and $10.5 \pm 2.1 \%$ was dissociated after $48 \mathrm{~h}$ and $144 \mathrm{~h}$, respectively. Also upon storage in $0.9 \% \mathrm{NaCl} /$ gentisic acid $5 \mathrm{mg} / \mathrm{ml}(\mathrm{pH} 5.0)$ at $4^{\circ} \mathrm{C}$ the 


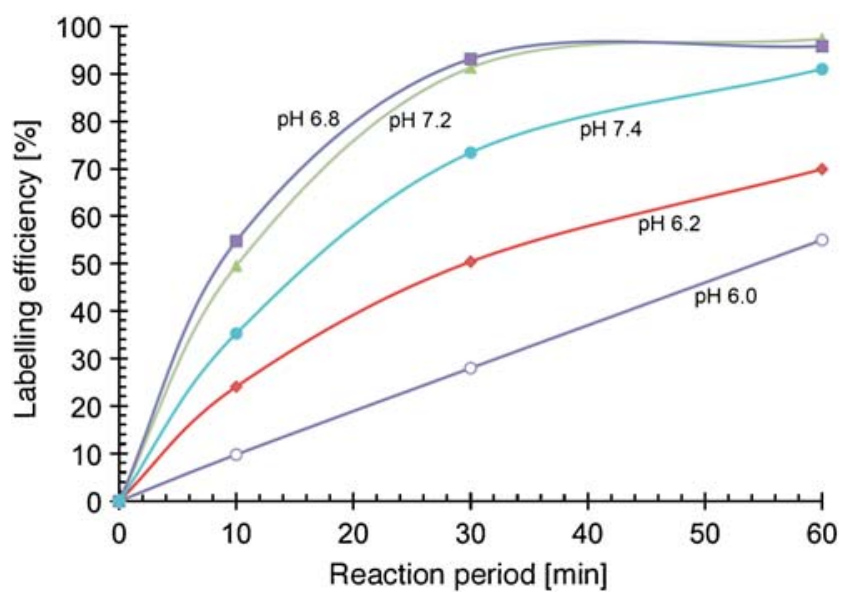

Fig. 2 Time course of ${ }^{89} \mathrm{Zr}$ complexation of $\mathrm{mAb}$ cU36 conjugated with Df-Bz-NCS at different $\mathrm{pH}$ and at room temperature

radioimmunoconjugates remained reasonably stable, showing $13.2 \pm 2.8 \%$ dissociation after $144 \mathrm{~h}$. However, storage in the same buffer at room temperature resulted in rapid release of radioactivity from the conjugate, $48.4 \pm 5.7 \%$. The corresponding ${ }^{89} \mathrm{Zr}-\mathrm{N}$-SucDf-mAb conjugates remained very stable, showing less than $5 \%$ release after $144 \mathrm{~h}$ under all conditions investigated.

The in vitro stability data for the ${ }^{89} \mathrm{Zr}$-Df-Bz-NCS-cU36 and ${ }^{89} \mathrm{Zr}-\mathrm{N}$-sucDf-cU36 conjugates, when incubated in freshly prepared human serum at $37^{\circ} \mathrm{C}$, showed that loss of ${ }^{89} \mathrm{Zr}$ from both conjugates over a 7-day period was very small. The percentages dissociated at day 3 were $2.3 \pm 0.1 \%$ for the DfBz-NCS conjugate and $3.4 \pm 0.6 \%$ for the $N$-sucDf conjugate, and at day 7 were $4.0 \pm 0.6 \%$ for the Df-Bz-NCS conjugate and $4.7 \pm 0.5 \%$ for the $N$-sucDf conjugate, respectively.

Evaluation of the in vivo biodistribution

Two sets of biodistribution studies were performed. In the first experiment, ${ }^{89} \mathrm{Zr}$-Df-Bz-NCS-cU36 and the reference compound ${ }^{89} \mathrm{Zr}-\mathrm{N}$-sucDf-cU36 were injected into $\mathrm{FaDu}$ bearing nude mice. At 72 and $144 \mathrm{~h}$ after injection, the average $\% \mathrm{ID} / \mathrm{g}$ of tumor, blood, normal tissue, and gastrointestinal contents was determined (Fig. 3). No significant differences in the biodistribution of both conjugates were found.

Only a minor proportion of $\mathrm{mAb}$ cU36 internalizes after binding to its target antigen, therefore in the second biodistribution study, the anti-EGFR mAb cetuximab was chosen because of the high rate of internalization. ${ }^{89} \mathrm{Zr}$-DfBz-NCS-cetuximab and the reference compound ${ }^{89} \mathrm{Zr}-\mathrm{N}$ sucDf-cetuximab were injected into A431-bearing nude mice. At 24, 48, 72, and $120 \mathrm{~h}$ after injection, the average $\% \mathrm{ID} / \mathrm{g}$ of tumor, blood, normal tissue, and gastrointestinal contents was determined (Fig. 4). The overall biodistribution of the two radioimmunoconjugates was very similar, showing no significant differences except for blood levels at 24 and $120 \mathrm{~h}$ after injection (Fig. 4; significant differences $(P<$ $0.01)$ are indicated with an asterisk). The ${ }^{89} \mathrm{Zr}$-Df-Bz-NCScetuximab tumor accumulation ranged from $15.6 \pm 4.4 \% \mathrm{ID} / \mathrm{g}$ to $23.1 \pm 7.1 \% \mathrm{ID} / \mathrm{g}$ and the ${ }^{89} \mathrm{Zr}-\mathrm{N}$-sucDf-cetuximab accumulation from $12.3 \pm 3.2 \% \mathrm{ID} / \mathrm{g}$ to $25.3 \pm 6.1 \% \mathrm{ID} / \mathrm{g}$, in the time period between 24 and $120 \mathrm{~h}$ post-injection.

\section{PET study}

To exclude ${ }^{89} \mathrm{Zr}$ uptake in tissues not evaluated in the biodistribution experiments, a PET imaging study was performed. Representative PET images of FaDu xenograft-bearing nude mice at $72 \mathrm{~h}$ after injection with ${ }^{89} \mathrm{Zr}$-Df-Bz-NCS-cU36 or ${ }^{89} \mathrm{Zr}-\mathrm{N}$-sucDf-cU36 are shown in Fig. $5 \mathrm{a}$ or $\mathrm{b}$, respectively. Immuno-PET with both radioimmunoconjugates revealed clear delineation of the tumors (arrows), whereas no prominent uptake of radioactivity was observed in other tissues, except for the liver in which ${ }^{89} \mathrm{Zr}$ residualizes after catabolism of the conjugates.

\section{Discussion}

Immuno-PET, the tracking and quantification of mAbs and $\mathrm{mAb}$-fragments with PET in vivo, is an emerging novel

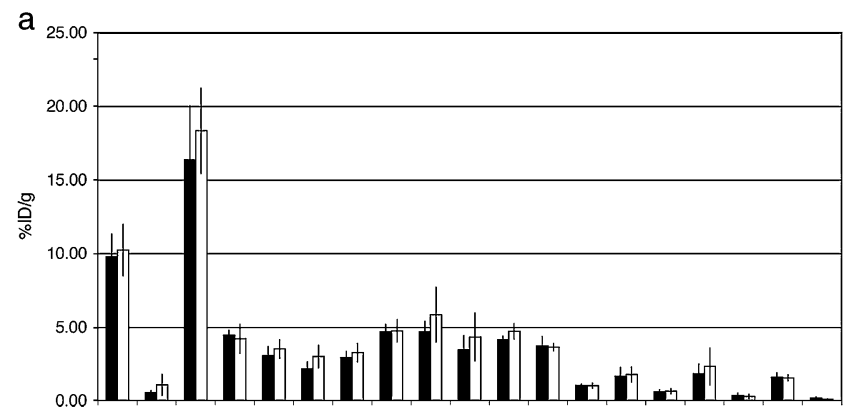

b

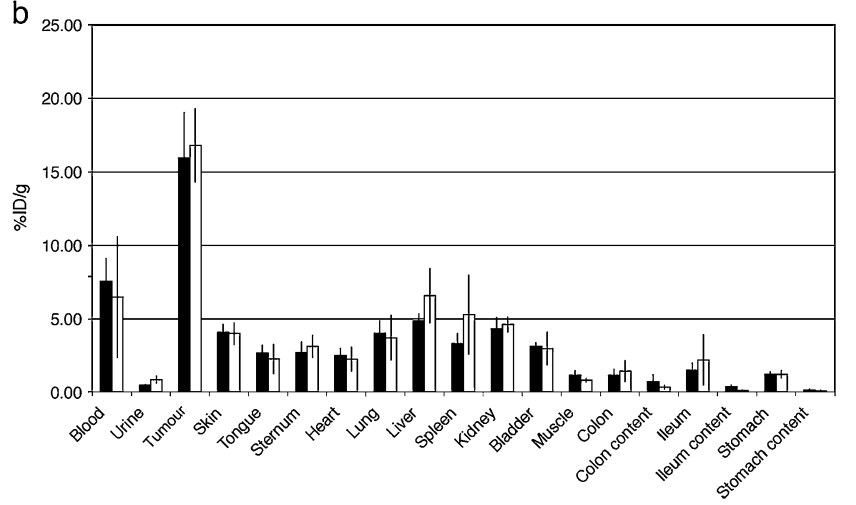

Fig. 3 Biodistribution of ${ }^{89} \mathrm{Zr}-\mathrm{Df}-\mathrm{Bz}-\mathrm{NCS}-\mathrm{cU} 36$ (black bars) and ${ }^{89} \mathrm{Zr}$ - $N$-sucDf-cU36 (white bars) in FaDu tumor-bearing nude mice at $72 \mathrm{~h} \mathrm{(a)} \mathrm{and} 144 \mathrm{~h} \mathrm{(b)} \mathrm{after} \mathrm{injection.} \mathrm{Total} \mathrm{administered} \mathrm{mAb} \mathrm{dose:}$ $100 \mu \mathrm{g}$. Mean $(\% \mathrm{ID} / \mathrm{g}) \pm \mathrm{SD}$ at each time point after injection $(n=4$ animals per time point for each conjugate) 

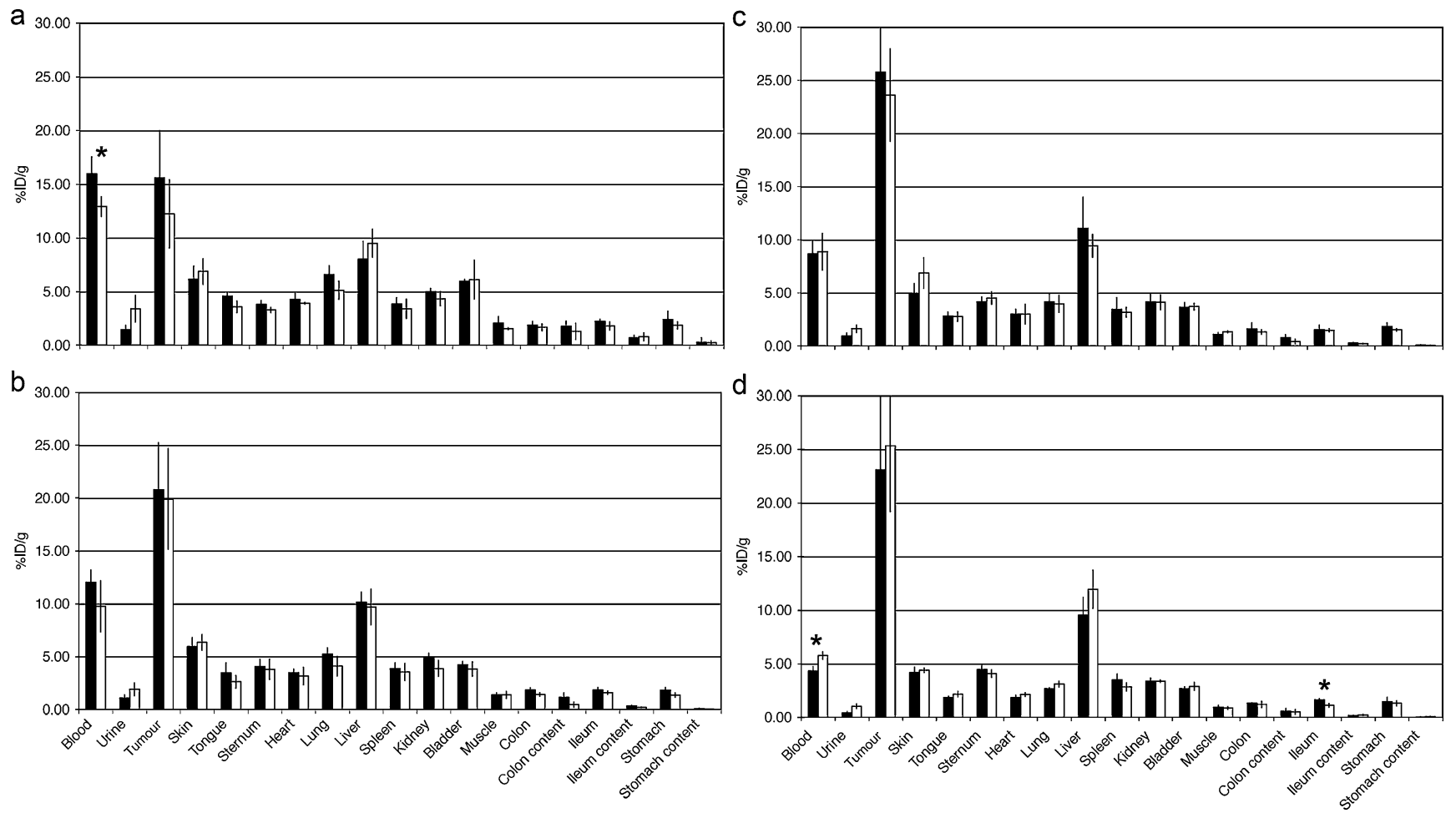

Fig. 4 Biodistribution of ${ }^{89} \mathrm{Zr}$-Df-Bz-NCS-cetuximab (black bars) and ${ }^{89} \mathrm{Zr}-\mathrm{N}$-sucDf-cetuximab (white bars) in A431 tumor-bearing nude mice at $24 \mathrm{~h}(\mathbf{a}), 48 \mathrm{~h}(\mathbf{b}), 72 \mathrm{~h} \mathrm{(c)}$, and $120 \mathrm{~h}(\mathbf{d})$ after injection. Total administered mAb dose: $500 \mu \mathrm{g}$. Mean $(\% \mathrm{ID} / \mathrm{g}) \pm \mathrm{SD}$ at each

time point after injection $(n=4$ animals per time point for each conjugate). Significant differences $(P<0.01)$ in biodistribution between both radioimmunoconjugates are marked with an asterisk

option to improve diagnostics and to guide mAb-based therapy [2-4]. Availability of positron emitters with a proper half-life, simple and robust radiochemistry, and advanced animal as well as clinical PET and PET-CT scanners, is crucial in these developments.

In the present report, we have described a method for labeling mAbs with the long-lived positron emitter ${ }^{89} \mathrm{Zr}$ using the novel bifunctional chelate Df-Bz-NCS. ${ }^{89} \mathrm{Zr}$ has attractive characteristics for immuno-PET with intact $\mathrm{mAbs}$, especially when these mAbs become internalized upon

Fig. 5 HRRT PET images (coronal slices) of two different $\mathrm{FaDu}$ xenograft-bearing nude mice at $72 \mathrm{~h}$ after injection with ${ }^{89} \mathrm{Zr}-\mathrm{Df}-\mathrm{Bz}-\mathrm{NCS}-\mathrm{cU} 36$ (a) or with ${ }^{89} \mathrm{Zr}-N$-sucDf-cU36 (b).

Slices from ventral (left) to dorsal (right). Images demonstrate high level of radiolabeled antibody accumulating in the tumor (arrows point to flank tumors) and low levels of tracer uptake in nontarget tissues

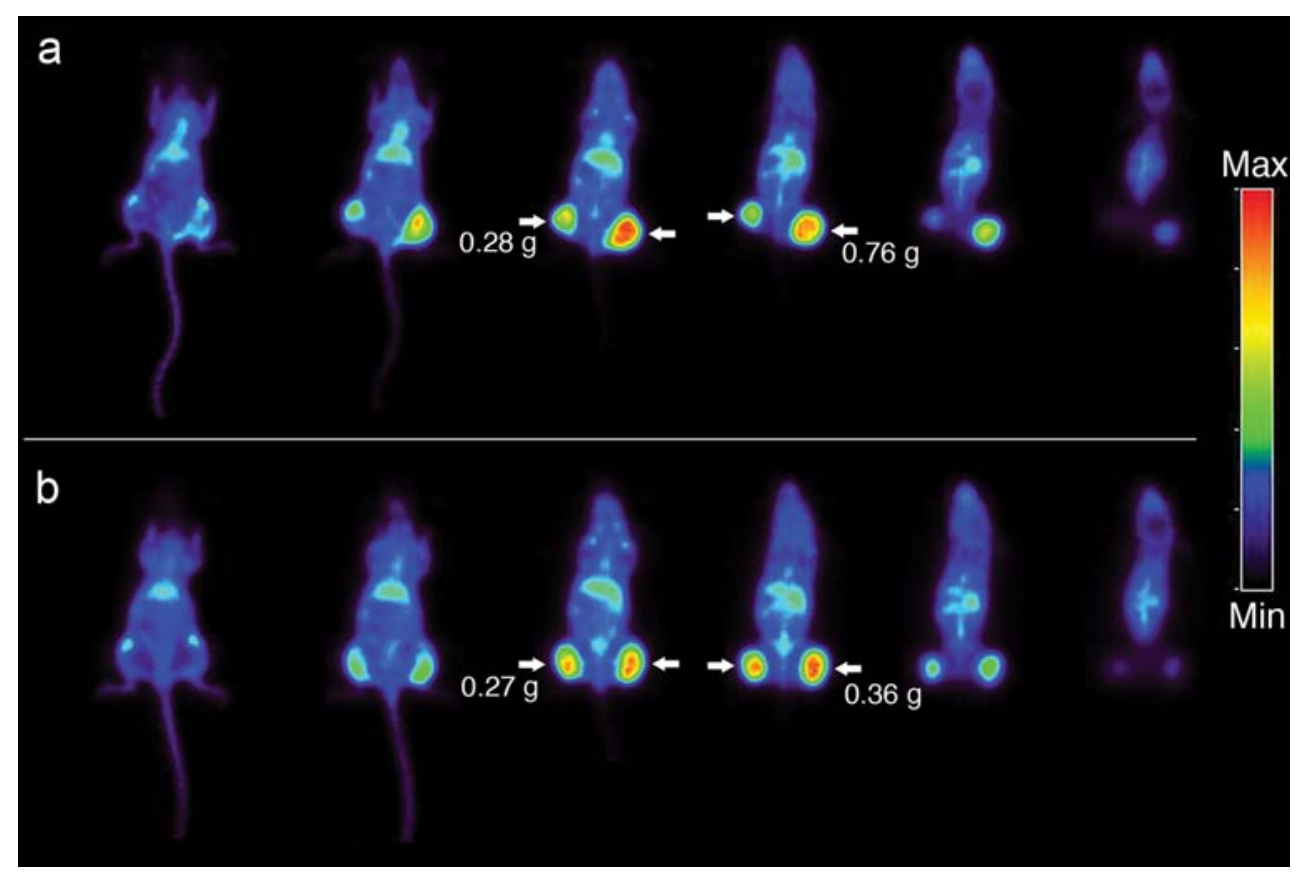


binding to their cellular target. Radioimmunoconjugates produced by this method were stable in storage buffer as well as in human serum in vitro. Biodistribution and imaging experiments showed high and selective accumulation in tumors in nude mice.

The chelate Df has frequently been used for radiolabeling of mAbs in the past, but these conjugates have never been evaluated clinically [24-27]. More recently, Verel et al. [5] developed a sophisticated method for stable coupling of ${ }^{89} \mathrm{Zr}$ to mAbs using a succinylated-derivative of $\mathrm{Df}$, which was used as the reference method in the present study (Fig. 1b). ${ }^{89} \mathrm{Zr}$-labeled mAbs prepared according to this method have been successfully tested preclinically and clinically [6-13]. In the past and ongoing clinical studies, neither adverse reactions nor significant changes in blood and urine values were observed after injection of these conjugates. Moreover, no antibody responses directed against the Df chelate were observed, indicating that its immunogenicity is low [8]. These data illustrate that ${ }^{89} \mathrm{Zr}$ labeled Df-mAbs can be used safely in patients. However, a shortcoming of the aforementioned method is that the multi-step procedure is relatively complicated and timeconsuming, and therefore challenging with respect to GMP compliance.

Now we introduce $p$-isothiocyanatobenzyl-derivative of Df (Df-Bz-NCS) that might provide an efficient and rapid preparation of ${ }^{89} \mathrm{Zr}$-labeled mAbs. Bifunctional chelates bearing isothiocyanate as the reactive group for conjugation to mAbs or other biologicals are frequently used [28]. The isothiocyanate group of the bifunctional chelate forms a thiourea bond with a primary amine of the protein or $\mathrm{mAb}$.

Coupling of Df-Bz-NCS to mAbs was very efficient. A reproducible chelate:mAb substitution ratio of 1.5:1 was obtained in a typical conjugation reaction with several different mAbs using only a three-fold molar excess of DfBz-NCS. The chelate:mAb substitution ratio was chosen to be kept below 2 to avoid alteration of the pharmacokinetics and immunoreactivity of the mAb $[29,30]$.

The rate of complexation of ${ }^{89} \mathrm{Zr}$ into the Df-Bz-NCS conjugate was very similar as compared to the reference $N$ sucDf conjugate reported by Verel et al. [5], indicating that the different chemical linkages (e.g., $=\mathrm{S}$ instead of $=\mathrm{O}$ group in the side chain, which might be involved in ${ }^{89} \mathrm{Zr}^{4+}$ coordination) have no influence on the complexation rate. At the $\mathrm{pH}$-optimum, almost quantitative complexation was reached after $30 \mathrm{~min}$ at room temperature. The resulting radioimmunoconjugates showed no impairment of immunoreactivity and integrity of the mAbs.

Radioimmunoconjugates were stored in various media to find the optimal conditions for storage and transportation over several days. The ${ }^{89} \mathrm{Zr}$-Df-Bz-NCS-mAb can best be stored at $4{ }^{\circ} \mathrm{C}$ in sodium acetate buffer in the presence of the antioxidant gentisic acid. Under these conditions, only a minor portion of the initially bound ${ }^{89} \mathrm{Zr}$ was dissociated from the $\mathrm{mAb}$ after $144 \mathrm{~h}$. The need for protection of the radioimmunoconjugate against radiation damage during storage has been shown in previous studies [5, 31]. The presence of the antioxidant ascorbic acid during storage of high-dose ${ }^{90} \mathrm{Y}$ - or ${ }^{131}$ I-labeled $\mathrm{mAbs}$ proved to be beneficial, however, ascorbic acid cannot be used during storage of ${ }^{89} \mathrm{Zr}$-labeled Df-mAbs, because this reagent causes detachment of ${ }^{89} \mathrm{Zr}$ from Df by reducing $\mathrm{Zr}^{4+}$ to $\mathrm{Zr}^{2+}[5]$.

Under certain storage conditions, the new ${ }^{89} \mathrm{Zr}$-Df-BzNCS conjugate is slightly less stable than the reference radioimmunoconjugate, and it is important to be aware of this. Especially the presence of $\mathrm{Cl}^{-}$-ions in the storage buffer impaired the integrity of the radioimmunoconjugates, most likely due to the radiation-induced formation of $\mathrm{OCl}^{-}$ions reacting with the SH-group of the enolised thioureaunit. The thus formed intermediary sulphenyl chloride bonds, and sulphonyl chloride bonds arising upon further oxidation, are known to undergo a series of reactions, among which are coupling reactions and cleavage of methionyl peptide bonds. ITLC data also indicated that most of the deterioration is not detachment of ${ }^{89} \mathrm{Zr}$ from the Df-chelate itself, but disruption of the Zr-Df unit.

The in vitro stability of the ${ }^{89} \mathrm{Zr}$-Df-Bz-NCS conjugate and the ${ }^{89} \mathrm{Zr}-\mathrm{N}$-sucDf conjugate was also compared in freshly prepared human serum at $37^{\circ} \mathrm{C}$. The stability of both conjugates under these conditions was very comparable and high, showing less than $4.7 \%$ release after a 7 -day incubation period. Serum acts as an oxidisable scavenger and protects against directs hits to the $\mathrm{mAb}$ molecule, minimizing the radiation-induced deterioration of the $\mathrm{mAb}$. Comparable in vitro stability data of ${ }^{89} \mathrm{Zr}-\mathrm{N}$-sucDf conjugates were previously reported by our group [21].

To investigate whether the new linker used for coupling of Df to the mAbs affects the biodistribution properties in mice, two sets of biodistribution experiments were performed. In the first experiment, the biodistribution of ${ }^{89} \mathrm{Zr}-\mathrm{Df}-\mathrm{Bz}-\mathrm{NCS}-\mathrm{cU} 36$ and the reference compound ${ }^{89} \mathrm{Zr}-\mathrm{N}$-sucDf-cU36 was compared in FaDu-bearing nude mice. In this model, no significant differences in the biodistribution between both conjugates were found. However, only a minor proportion of $\mathrm{mAb} \mathrm{cU} 36$ internalizes after binding to its target antigen, therefore in the second biodistribution study the anti-EGFR mAb cetuximab was chosen because of the high rate of internalization [21]. Also in this model, a very similar biodistribution was found. Nevertheless, some significant differences were found, e.g. blood levels at 24 and $120 \mathrm{~h}$ after injection. Overall, both studies indicate that the different linkers used do not affect the biodistribution properties in nude mice. Moreover, none of the normal organs showed an adverse high uptake. The aforementioned results were confirmed in comparative 
immuno-PET studies with both chelates. PET images did not show accumulation of radioactivity in bone, which would have been indicative of free ${ }^{89} \mathrm{Zr}$.

\section{Conclusions}

In the present study we evaluated the newly developed bifunctional chelate Df-Bz-NCS for radiolabeling of mAbs with ${ }^{89} \mathrm{Zr}$ for PET-imaging. The two-step procedure allows efficient and rapid preparation of ${ }^{89} \mathrm{Zr}$-labeled mAbs. Resulting ${ }^{89}$ Zr-Df-Bz-NCS-mAb conjugates appeared optimal with respect to radiochemical purity, integrity, and immunoreactivity. Furthermore, the radioimmunoconjugates were stable in serum in vitro and comparative biodistribution and imaging experiments showed high and selective accumulation in tumors in nude mice. Special emphasis should be given to the storage conditions. The recent commercialization of ${ }^{89} \mathrm{Zr}$ and the availability of an easy-to-use radiolabeling strategy using Df-Bz-NCS allow further exploration of ${ }^{89} \mathrm{Zr}$-immuno-PET as an imaging tool for the selection of high potential candidate mAbs for therapy as well as for the selection of patients with the highest chance of benefit from mAb-based therapy [2].

Acknowledgments This project was financially supported by the Dutch Technology Foundation (STW, grants VBC.6120 and 10074) and partly supported by the European Union FP7, ADAMANT. The publication reflects only the authors' views. The European Commission is not liable for any use that may be made of the information contained. The authors thank the technical staff of BV Cyclotron VU and the Radionuclide Centre for supply and processing of ${ }^{89} \mathrm{Zr}$, Marc Huisman for PET analyses, and Marijke Stigter-van Walsum for technical assistance with animal studies.

\section{Conflict of interest none.}

Open Access This article is distributed under the terms of the Creative Commons Attribution Noncommercial License which permits any noncommercial use, distribution, and reproduction in any medium, provided the original author(s) and source are credited.

\section{References}

1. Carter PJ. Potent antibody therapeutics by design. Nat Rev Immunol. 2006;6:343-57.

2. van Dongen GAMS, Visser GWM, Lub-de Hooge MN, de Vries EG, Perk LR. Immuno-PET: a navigator in monoclonal antibody development and applications. Oncologist. 2007;12:1379-89.

3. Wu AM. Antibodies and antimatter: the resurgence of immunoPET. J Nucl Med. 2009;50:2-5.

4. Nayak TK, Brechbiel MW. Radioimmunoimaging with longerlived positron-emitting radionuclides: potentials and challenges. Bioconjug Chem. 2009;20:825-41.
5. Verel I, Visser GWM, Boellaard R, Stigter-van Walsum M, Snow GB, van Dongen GAMS. ${ }^{89} \mathrm{Zr}$ immuno-PET: comprehensive procedures for the production of ${ }^{89} \mathrm{Zr}$-labeled monoclonal antibodies. J Nucl Med. 2003;44:1271-1281.

6. Dijkers E, Lub-de Hooge MN, Kosterink JG, et al. Characterization of ${ }^{89} \mathrm{Zr}$-trastuzumab for clinical HER2 immunoPET imaging. J Clin Oncol. 2007;25:3508. (meeting abstracts).

7. Perk LR, Stigter-van Walsum M, Visser GWM, et al. Quantitative PET imaging of Met-expressing human cancer xenografts with ${ }^{89} \mathrm{Zr}$-labelled monoclonal antibody DN30. Eur J Nucl Med Mol Imaging. 2008;35:1857-67.

8. Borjesson PKE, Jauw YWS, Boellaard R, et al. Performance of immuno-positron emission tomography with zirconium-89labeled chimeric monoclonal antibody U36 in the detection of lymph node metastases in head and neck cancer patients. Clin Cancer Res. 2006;12:2133-40.

9. Nagengast WB, de Vries EG, Hospers GA, et al. In vivo VEGF imaging with radiolabeled bevacizumab in a human ovarian tumor xenograft. J Nucl Med. 2007;48:1313-19.

10. Verel I, Visser GWM, Boerman OC, et al. Long-lived positron emitters zirconium-89 and iodine-124 for scouting of therapeutic radioimmunoconjugates with PET. Cancer Biother Radiopharm. 2003; 18:655-61.

11. Verel I, Visser GWM, Boellaard R, et al. Quantitative ${ }^{89} \mathrm{Zr}$ immuno-PET for in vivo scouting of ${ }^{90} \mathrm{Y}$-labeled monoclonal antibodies in xenograft-bearing nude mice. J Nucl Med. 2003;44:1663-70.

12. Brouwers A, Verel I, Van Eerd J, et al. PET radioimmunoscintigraphy of renal cell cancer using ${ }^{89} \mathrm{Zr}$-labeled cG250 monoclonal antibody in nude rats. Cancer Biother Radiopharm. 2004;19:15563.

13. Perk LR, Visser OJ, Stigter-van Walsum M, et al. Preparation and evaluation of ${ }^{89} \mathrm{Zr}$-Zevalin for monitoring of ${ }^{90} \mathrm{Y}$-Zevalin biodistribution with positron emission tomography. Eur J Nucl Med Mol Imaging. 2006;33:1337-45.

14. Mendelsohn J, Baselga J. Epidermal growth factor receptor targeting in cancer. Semin Oncol. 2006;33:369-85.

15. Schrijvers AH, Quak JJ, Uyterlinde AM, et al. MAb U36, a novel monoclonal antibody successful in immunotargeting of squamous cell carcinoma of the head and neck. Cancer Res. 1993;53:4383-90.

16. Rangan SR. A new human cell line $(\mathrm{FaDu})$ from a hypopharyngeal carcinoma. Cancer. 1972;29:117-21.

17. Welters MJ, Fichtinger-Schepman AM, Baan RA, et al. Relationship between the parameters cellular differentiation, doubling time and platinum accumulation and cisplatin sensitivity in a panel of head and neck cancer cell lines. Int J Cancer. 1997;71:410-15.

18. Bifunctional hydroxamic acid ligands and method of synthesis. Jurek P. PCT WO 2008/124467

19. Lindmo T, Boven E, Cuttitta F, Fedoroko J, Bunn PA Jr. Determination of the immunoreactive fraction of radiolabeled monoclonal antibodies by linear extrapolation to binding at infinite antigen excess. J Immunol Methods. 1984;72:77-89.

20. Meares CF, McCall MJ, Reardan DT, Goodwin DA, Diamanti CI, McTique M. Conjugation of antibodies with bifunctional chelating agents: isothiocyanate and bromoacetamide reagents, methods of analysis, and subsequent addition of metal ions. Anal Biochem. 1984;142:68-78.

21. Perk LR, Visser GWM, Vosjan MJWD, et al. ${ }^{89} \mathrm{Zr}$ as a PET surrogate radioisotope for scouting biodistribution of the therapeutic radiometals ${ }^{90} \mathrm{Y}$ and ${ }^{177} \mathrm{Lu}$ in tumor-bearing nude mice after coupling to the internalizing antibody cetuximab. J Nucl Med. 2005;46:1898-06.

22. de Jong HWAM, van Velden FHP, Kloet RW, Buijs FL, Boellaard R, Lammertsma AA. Performance evaluation of the ECAT HRRT: an LSO-LYSO double-layer high-resolution, high-sensitivity scanner. Phys Med Biol. 2007;52:1505-26. 
23. Loening AM, Gambhir SS. AMIDE: a free software tool for multimodality medical image analysis. Mol Imaging. 2003;2:131-37.

24. Yokoyama A, Ohmomo Y, Horiuchi K, et al. Deferoxamine, a promising bifunctional chelating agent for labeling proteins with gallium: Ga-67 DF-HSA: concise communication. J Nucl Med. 1982;23:909-14.

25. Koizumi M, Endo K, Kunimatsu M, et al. ${ }^{67}$ Ga-labeled antibodies for immunoscintigraphy and evaluation of tumor targeting of drug-antibody conjugates in mice. Cancer Res. 1988;48:1189-94.

26. Pochon S, Buchegger F, Pelegrin A, et al. A novel derivative of the chelon desferrioxamine for site-specific conjugation to antibodies. Int J Cancer. 1989;43:1188-94.

27. Meijs WE, Haisma HJ, Klok RP, et al. Zirconium-labeled monoclonal antibodies and their distribution in tumor-bearing nude mice. J Nucl Med. 1997;38:112-18.
28. Liu S. Bifunctional coupling agents for radiolabeling of biomolecules and target-specific delivery of metallic radionuclides. Adv Drug Deliv Rev. 2008;60:1347-70.

29. van Gog FB, Visser GWM, Klok RP, van der Schors R, Snow GB, van Dongen GAMS. Monoclonal antibodies labeled with rhenium-186 using the MAG3 chelate: relationship between the number of chelated groups and biodistribution characteristics. J Nucl Med. 1996;37:352-62.

30. Kukis DL, DeNardo GL, DeNardo SJ, et al. Effect of the extent of chelate substitution on the immunoreactivity and biodistribution of 2IT-BAT-Lym-1 immunoconjugates. Cancer Res. 1995;55:87884.

31. Chakrabarti MC, Le N, Paik CH, De Graff WG, Carrasquillo JA. Prevention of radiolysis of monoclonal antibody during labeling. J Nucl Med. 1996;37:1384-88. 